DE

M E D I C I N A

T R O P I C A L

$\mathrm{DE}$

SÃO PAULO

JOURNAL OF THE SÃO PAULO INSTITUTE OF TROPICAL MEDICINE

1 Universidade Federal da Grande Dourados, Laboratório de Pesquisa em Ciências da Saúde Dourados, Mato Grosso do Sul, Brazil

2Universidade Federal da Grande Dourados, Hospital Universitário de Dourados, Dourados, Mato Grosso do Sul, Brazil

${ }^{3}$ Fundação Oswaldo Cruz, Campo Grande, Mato Grosso do Sul, Brazil

${ }^{4}$ Universidade Federal de Mato Grosso do Sul, Faculdade de Medicina, Campo Grande, Mato Grosso do Sul, Brazil

Correspondence to: Simone Simionatto Universidade Federal da Grande Dourados, Laboratório de Pesquisa em Ciências da Saúde, Rodovia Dourados-Itahum, Km 12, Cidade Universitária, CEP 79804970 , Dourados, MS, Brazil

Tel: +55 67 3410-2225, +55 67 99958-5355

E-mail: simonesimionatto@ufgd.edu.br

Received: 14 May 2020

Accepted: 3 September 2020

\section{Neurosyphilis in Brazilian newborns: a health problem that could be avoided}

\author{
Anny Danyelly da Costa Ribeiro ${ }^{1,2}$, Cristiane de Sá Dan ${ }^{1,2}$, Andrea da \\ Silva Santos ${ }^{(1)}$, Júlio Croda ${ }^{3,4}$, Simone Simionatto ${ }^{(1)}$
}

\section{ABSTRACT}

Syphilis is a public health problem, especially in pregnant women, due to the risk of transmission to the fetus and the involvement of the central nervous system, causing neurosyphilis. A case-control study was carried out to analyze the variables associated with neurosyphilis in Brazilian newborns of pregnant women with syphilis admitted for childbirth. Newborns were submitted to treponemal and non-treponemal tests, cerebrospinal fluid analysis, and long bone radiography. Newborns diagnosed with neurosyphilis and congenital syphilis were defined as cases and controls, respectively. The length of hospitalization and mean cost of neurosyphilis treatment were also evaluated. Twenty-one cases of newborns with neurosyphilis and 42 controls with congenital syphilis were included in the study. Out of 63 pregnant women with syphilis, 95.2\% (60/63) received prenatal care, 74.6\% (47/63) were diagnosed with syphilis during this period, $31.9 \%$ (15/47) underwent treponemic tests, $80.8 \%$ (38/47) were treated with penicillin and only $46.8 \%(22 / 47)$ of the partners received the treatment. Clinical complications such as low birth weight were observed in $12.7 \%(8 / 63)$ of the newborns. About 50.8\% (32/63) of the newborns were hospitalized due to syphilis complications and each case of neurosyphilis spent at least US\$ 881.48 on treatment and hospitalization. The results showed that the prenatal coverage is not sufficient to prevent neurosyphilis. The late diagnosis of syphilis in pregnant women and inadequate follow-up of sexual partners may favor the vertical transmission of T. pallidum in pregnant Brazilian women. Thus, improving the quality of health services is important for a more effective control of neurosyphilis.

KEYWORDS: Syphilis. Neurosyphilis. Risk factors. Newborns. Pregnant women. Congenital infections. Congenital syphilis.

\section{INTRODUCTION}

Syphilis, an infectious, sexually transmitted disease, remains a major public health problem in the world with several clinical manifestations ${ }^{1}$. The occurrence of syphilis in its different forms can be a predictor of important health services failures and its increase has raised national concern in recent years ${ }^{2}$. The World Health Organization (WHO) estimates more than 11 million new cases every year, and more than $90 \%$ of them occur in developing countries, such as Brazil ${ }^{1,3,4}$. Treponema pallidum is the etiologic agent of syphilis, and in pregnant women the infection has a potential risk of vertical transmission ${ }^{5}$.

Gestational syphilis affects approximately 1.5 million pregnant women per year worldwide, and nearly half of the untreated pregnant women present with adverse outcomes ${ }^{3}$. A meta-analysis showed that $25.6 \%$ of the pregnant women 
infected with T. pallidum evolved with abortions or stillbirths, $15.5 \%$ had clinical evidence of syphilis, $12.3 \%$ of the newborns died and $12.1 \%$ were born preterm or with low birth weight ${ }^{6}$. In Brazil ${ }^{7}$, the prevalence of $T$. pallidum infection in pregnant women is $1.6 \%$. In 2017 , about 24,666 cases of congenital syphilis were reported, corresponding to a $17 \%$ increase compared with the previous year. In this period, the rate of death from congenital syphilis in children under one year of age was 7.2 per 100,000 live births, showing an insufficient control of the disease throughout the national territory ${ }^{8}$.

During pregnancy, T. pallidum is transmitted to the fetus through the transplacental route. It can affect the central nervous system (CNS), causing neurosyphilis, with varied clinical manifestations, ranging from cerebrospinal fluid changes in asymptomatic newborns to more serious symptomatology such as progressive general paralysis. More than $50 \%$ of children infected with T. pallidum are asymptomatic at birth. Moreover, about $23 \%$ of infants born to mothers with syphilis have neurosyphilis. Thus, one of the major concerns of this congenital disease, even if asymptomatic, is the possibility of involvement of the $\mathrm{CNS}^{9,10}$. The diagnosis of neurosyphilis is complex, with the cerebrospinal fluid (CSF) evaluation as the only way to diagnose asymptomatic neurosyphilis. Although a positive VDRL in CSF is considered specific for neurosyphilis, it has limited sensitivity ${ }^{11-13}$.

Interventions aimed at preventing and timely diagnosing syphilis during the prenatal care are recommended to control this disease ${ }^{14}$, as behavioral, socio-demographic and health care factors are considered facilitators of syphilis in pregnant women ${ }^{15}$. Despite the increase in new cases of syphilis in Brazil, neurosyphilis is not sufficiently studied. The purpose of this study was to analyze the variables associated with neurosyphilis in Brazilian newborns and assist in implementing public health strategies to control the disease.

\section{METHODS}

\section{Study design}

This is a case control study carried out in a University Hospital (HU) from the Midwest region of Brazil. Mato Grosso do Sul (MS) is a state in the Midwest of Brazil bordering Paraguay and Bolivia, with a population of 2.5 million people. The study was conducted from July to December 2017 with parturients admitted to a maternity ward of the HU of Dourados, Midwest of Brazil. The HU is a public hospital with 237 beds that provides medium to high complex assistance in various medical specialties.
It is the only referral hospital for attending high-risk pregnancies in 34 municipalities, with approximately 900,000 inhabitants, with an average of 1,000 visits and 300 births per month.

\section{Study population}

The study included newborns of parturient who were 18 years of age or older, with the diagnosis of syphilis, admitted to the HU maternity ward. They should be mentally competent to understand the research and agree to participate. The parturients were screened using treponemal and non-treponemal serological tests. Those who tested positive, irrespective of the titer, had their newborns screened following the protocol of the Ministry of Health, which included treponemal and nontreponemal serological tests, cerebrospinal fluid and long bones radiography. Newborns with altered cerebrospinal fluid (CSF) analysis and diagnosed with neurosyphilis, were considered a case. Newborns without CSF changes and diagnosed with congenital syphilis, were defined as a control. Each case was further randomly matched with two paired controls.

\section{Data collection}

Data collection was performed during admission for childbirth in two stages. Firstly, each parturient was interviewed using a standardized questionnaire. The variables obtained included age, marital status, education level, drug use, sexual history, diagnosis of sexually transmitted infections (STI), obstetric data, prenatal care, diagnosis and treatment of syphilis. The skin color of the participant (white and non-white) was selfreported. Secondly, medical charts and prenatal records of the participants were Newborns data were obtained from their medical records. A team of previously trained health professionals performed the interviews and data collection.

\section{Serological tests}

For serological tests, $10 \mathrm{~mL}$ and $3 \mathrm{~mL}$ of peripheral venous blood were collected by a team of previously trained health professionals from the parturients and newborns, respectively. Parturients were screened during admission using the rapid treponemal test (ABON Biopharm, Hangzhou, China) and the enzyme immunoassay (ELISA) (ICE* Syphilis, DiaSorin, Saluggia, Italy) for the detection of IgG and IgM anti- T. pallidum. Reagent (positive) samples were serially diluted and titrated with respect 
to anti-cardiolipin antibodies by the Venereal Disease Research Laboratory (VDRL) test (Abbott Murex, Dartford, UK). VDRL titers were used to determine treatment insufficiency or immunological memory in pregnant women. Blood samples of newborns from mothers with reactive serological results were tested using the treponemal and the VDRL tests.

\section{Lumbar puncture}

The newborns were immobilized in the fetal position, and disinfection of the puncture site was performed with iodine solution (1\% to $2 \%$ iodine dye or $10 \%$ povidoneiodine). The CSF sample was obtained by lumbar puncture using a hypodermic needle and syringe with a minimum volume of $2 \mathrm{~mL}$. The CSF collected was stored in a sterile flask until the analysis. The collection was performed by a pediatrician using an aseptic technique.

\section{Cerebrospinal fluid analysis}

The CSF samples of the newborns were tested using the VDRL test. A case of neurosyphilis was considered if the newborn presented with one or more of the following: any titer in the VDRL test, high protein levels $\left(>150 \mathrm{mg} / \mathrm{dL}\right.$ ), and leukocyte count ( $>25$ leukocytes $/ \mathrm{mm}^{3}$ of CSF) (6.14).

\section{Data analysis}

The results of the interview and serological tests were recorded in the Electronic Data Capture program (REDCap) and analyzed by the statistical software SAS (version 9.2, SAS Institute, Cary, NC, USA). The descriptive measures, the absolute frequencies and percentages were calculated in the univariate analysis. The Chi-squared test was used to compare the characteristics of the cases and the control group. The univariate analysis verified the association between the independent and dependent variables. The odds ratio (OR) and the confidence interval of $95 \%$ (95\% CI) were calculated. The level of statistical significance adopted was $\mathrm{p} \leq 0.05$.

\section{Ethical considerations}

This study was carried out after the approval of the research ethics committee from the Federal University of Grande Dourados ( $\left.\mathrm{N}^{\circ} 1.402 .529\right)$. All eligible participants were provided with an Informed Consent Form, as noted in Resolution 466 of December 12, 2012, from the Brazilian National Health Council.

\section{RESULTS}

In $2017,5,470$ births were registered in Dourados, of which 3,486 were in the $\mathrm{HU}$, which represents $63.7 \%$ of the total births. In the HU, 199 cases of pregnant women with syphilis and 167 cases of congenital syphilis were registered during the study period. The incidence rate of congenital syphilis was 4,790 per 100,000 live births. Sixty-three pregnant women with syphilis that agreed to participate in this study were included (Figure 1).

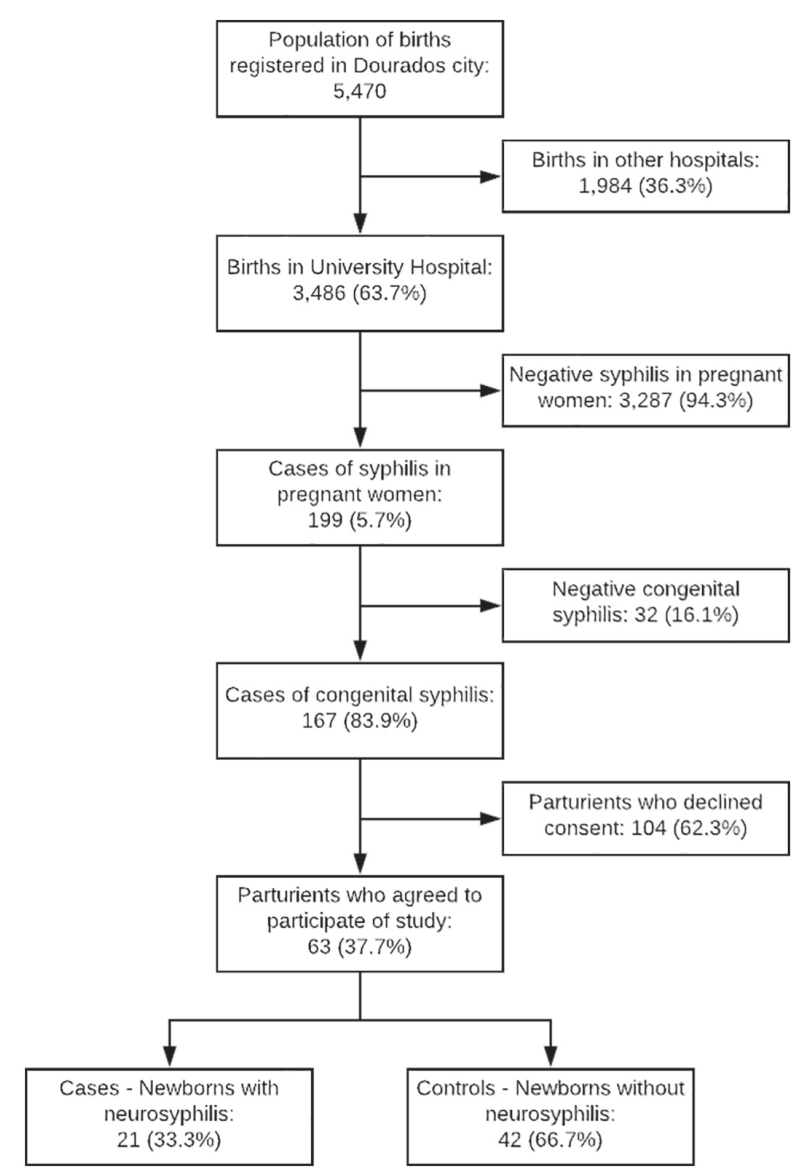

Figure 1 - Flowchart of cases of congenital syphilis in the University Hospital, Dourados, Mato Grosso do Sul State, Brazil, from July to December, 2017.

From the total of 63 women with syphilis admitted for childbirth, $33.3 \%$ (21/63) were over 30 years of age, $63.5 \%$ (40/63) did not complete the primary education, $82.5 \%$ $(52 / 63)$ declared themselves as non-white, $66.7 \%(42 / 63)$ were married, $65 \%$ (41/63) were unemployed, and $71.4 \%$ (45/63) lived in Dourados. Seventy-three percent (46/63) had income less than one minimum wage, 55.6\% (35/63) had their first sexual experience at $\geq 15$ years of age, and $90.5 \%$ (57/63) reported not using condoms during sexual intercourses. Table 1 shows the distribution of the main sociodemographic and behavioral variables of pregnant women. 
Table 1 - Sociodemographic characteristics and risk behaviors of pregnant women admitted for delivery at University Hospital of Dourados, Mato Grosso do Sul State.

\begin{tabular}{|c|c|c|c|c|c|c|}
\hline Variable & $\begin{array}{c}\text { Total } \\
\mathrm{n}=63\end{array}$ & $\begin{array}{c}\text { Case } \\
\mathrm{n}=21\end{array}$ & $\begin{array}{c}\text { Control } \\
n=42\end{array}$ & OR & $95 \% \mathrm{Cl}$ & $p$ value \\
\hline Age (years) & & & & & & 0.201 \\
\hline$<20$ & $11(17.5)$ & $4(19)$ & $7(16.7)$ & 1 & & \\
\hline $20-25$ & $18(28.6)$ & $4(19)$ & $14(33.3)$ & 0.50 & $0.09-2.62$ & \\
\hline $25-30$ & $13(20.6)$ & $2(9.5)$ & $11(26.2)$ & 0.31 & $0.04-2.22$ & \\
\hline 30 & $21(33.3)$ & $11(52.5)$ & $10(23.8)$ & 1.92 & $0.43-8.60$ & \\
\hline Education level & & & & 1.10 & $0.37-3.27$ & 0.854 \\
\hline Elementary school & $40(63.5)$ & $13(62)$ & $27(64)$ & & & \\
\hline High school & $23(36.5)$ & $8(38)$ & $15(36)$ & & & \\
\hline Skin color & & & & 0.85 & $0.21-3.30$ & 0.815 \\
\hline White & $11(17.5)$ & $4(19)$ & $7(16.7)$ & & & \\
\hline Non-white & $52(82.5)$ & $17(81)$ & 35 (83.3) & & & \\
\hline Marital status & & & & 1.00 & $0.32-3.03$ & 1.00 \\
\hline Married & $42(66.7)$ & $14(66.7)$ & $28(66.7)$ & & & \\
\hline Single & $21(33.3)$ & 7 (33.3) & $14(33.3)$ & & & \\
\hline Occupation & & & & 0.65 & $0.20-2.01$ & 0.458 \\
\hline Unemployed & $41(65)$ & $15(71.4)$ & $26(61.9)$ & & & \\
\hline Other occupation & $22(35)$ & $6(28.6)$ & $16(38.1)$ & & & \\
\hline City & & & & 3.33 & $0.84-13.19$ & 0.086 \\
\hline Dourados & $45(71.4)$ & $18(85.7)$ & $27(42.3)$ & & & \\
\hline Others & $18(28.6)$ & $3(14.3)$ & $15(57.7)$ & & & \\
\hline Wage & & & & 1.12 & $0.34-3.63$ & 0.842 \\
\hline$<1$ minimum wage & $46(73)$ & $15(71.4)$ & $31(73.9)$ & & & \\
\hline$\geq 1$ minimum wage & $17(27)$ & $6(28.6)$ & $11(26.1)$ & & & \\
\hline Age of first sexual experience & & & & 1.10 & $0.38-3.16$ & 0.858 \\
\hline$\leq 14$ years & $28(44.4)$ & $9(43)$ & $19(45.2)$ & & & \\
\hline$\geq 15$ years & $35(55.6)$ & $12(57)$ & $23(54.8)$ & & & \\
\hline Condom use & & & & 1.00 & $0.16-5.95$ & 1.000 \\
\hline Yes & $6(9.5)$ & $2(9.5)$ & $4(9.5)$ & & & \\
\hline No & $57(90.5)$ & $19(90.5)$ & $38(90.5)$ & & & \\
\hline Sexual partners in the last two years & & & & 1.00 & $0.32-3.03$ & 1.000 \\
\hline 1 & $42(66.7)$ & $14(66.7)$ & $28(66.7)$ & & & \\
\hline$\geq 2$ & $21(33.3)$ & 7 (33.3) & $14(33.3)$ & & & \\
\hline Sexual activity with inmate & & & & 1.41 & $0.33-5.98$ & 0.641 \\
\hline Yes & $11(17.5)$ & $3(14.3)$ & $8(19.5)$ & & & \\
\hline No & $52(82.5)$ & $18(85.7)$ & $34(80.5)$ & & & \\
\hline Tattoo & & & & 5.14 & $1.47-17.90$ & 0.010 \\
\hline Yes & $27(42.9)$ & $4(19.5)$ & $23(54.7)$ & & & \\
\hline No & $36(57.1)$ & $17(80.5)$ & $19(45.3)$ & & & \\
\hline Piercing & & & & 2.12 & $0.60-7.52$ & 0.240 \\
\hline Yes & $18(28.6)$ & $4(19.5)$ & $14(33.3)$ & & & \\
\hline No & $45(71.4)$ & $17(80.5)$ & $28(66.7)$ & & & \\
\hline Smoking & & & & 2.12 & $0.52-8.65$ & 0.287 \\
\hline Yes & $14(22.2)$ & $3(14.3)$ & $11(26.2)$ & & & \\
\hline No & $49(77.8)$ & $18(85.7)$ & $31(73.8)$ & & & \\
\hline Alcohol use & & & & 2.50 & $0.74-8.44$ & 0.140 \\
\hline Yes & $49(77.8)$ & $14(66.7)$ & 35 (83.3) & & & \\
\hline No & $14(22.2)$ & 7 (33.3) & 7 (16.7) & & & \\
\hline Illicit drug use & & & & 5.02 & 0.2597 .86 & 0.974 \\
\hline Yes & $4(6.4)$ & $0(0)$ & $4(9.5)$ & & & \\
\hline No & 59 (93.6) & $21(100)$ & $38(90.5)$ & & & \\
\hline
\end{tabular}


In addition, 95.2\% (60/63) of pregnant women received prenatal care, and only $60 \%(36 / 60)$ started it in the first trimester of pregnancy. Among these, 74.6\% (47/63) were diagnosed with syphilis during the prenatal care, $31.9 \%$ $(15 / 47)$ underwent treponemic tests, and $80.8 \%$ were treated with penicillin (38/47). Table 2 shows the variables related to prenatal and maternity care (clinical and obstetrical) for pregnant women. Table 2 shows the variables related to the clinical and the obstetric history and health care in the prenatal and maternity periods for the cases and controls.

Table 2 - Obstetric, prenatal and maternity health care for syphilis in pregnant women at the University Hospital of Dourados, Mato Grosso do Sul State.

\begin{tabular}{|c|c|c|c|c|c|c|}
\hline Variable & $\begin{array}{c}\text { Total } \\
n=63\end{array}$ & $\begin{array}{c}\text { Case } \\
\mathrm{n}=21\end{array}$ & $\begin{array}{c}\text { Control } \\
n=42\end{array}$ & OR & $95 \% \mathrm{Cl}$ & $p$ value \\
\hline Prenatal care & & & & 0.26 & $0.01-5.32$ & 0.213 \\
\hline Yes & $60(95.2)$ & $21(100)$ & $39(92.8)$ & & & \\
\hline No & $3(4.8)$ & $0(0)$ & $3(7.2)$ & & & \\
\hline Place of prenatal care & & & & 1.55 & 0.06-39.79 & 0.479 \\
\hline Public & $59(98.3)$ & $21(100)$ & $41(97.6)$ & & & \\
\hline Private & $1(1.7)$ & $0(0)$ & $1(2.7)$ & & & \\
\hline Beginning of prenatal care & & & & 1.20 & $0.40-3.52$ & 0.742 \\
\hline $1^{\circ}$ trimester & $36(60)$ & $12(57.1)$ & $24(61.5)$ & & & \\
\hline $2^{\circ}$ or $3^{\circ}$ trimester & $24(40)$ & $9(42.9)$ & $15(38.5)$ & & & \\
\hline Medical visits & & & & 0.88 & $0.28-2.76$ & 0.840 \\
\hline$\leq 5$ & $41(68.3)$ & $14(66.7)$ & $27(69.2)$ & & & \\
\hline$\geq 6$ & $19(31.7)$ & 7 (33.3) & $12(30.8)$ & & & \\
\hline History of abortion & & & & 0.70 & $0.22-2.21$ & 0.557 \\
\hline Yes & $18(28.6)$ & 7 (33.3) & $11(26.1)$ & & & \\
\hline No & $45(71.4)$ & $14(66.7)$ & $31(73.9)$ & & & \\
\hline History of stillbirth & & & & 2.10 & $0.22-20.11$ & 0.513 \\
\hline Yes & $5(8)$ & $1(4.7)$ & $4(9.5)$ & & & \\
\hline No & $58(92)$ & $20(95.3)$ & $38(90.5)$ & & & \\
\hline History of preterm birth $<37$ weeks & & & & 0.89 & $0.29-2.74$ & 0.849 \\
\hline Yes & $20(31.8)$ & 7 (33.3) & $13(30.9)$ & & & \\
\hline No & $43(68.2)$ & $14(66.7)$ & $29(69.1)$ & & & \\
\hline History of neonatal death & & & & 1.53 & $0.15-15.75$ & 0.717 \\
\hline Yes & $4(6.4)$ & $1(4.7)$ & $3(7.1)$ & & & \\
\hline No & $59(93.6)$ & $20(95.3)$ & 39 (92.9) & & & \\
\hline History of STI in the last year & & & & 0.61 & $0.21-178$ & 0.376 \\
\hline Yes & $31(49.2)$ & $12(57.1)$ & $19(45.2)$ & & & \\
\hline No & $32(50.8)$ & $9(42.9)$ & $23(54.8)$ & & & \\
\hline Genital injury & & & & 1.14 & $0.32-3.98$ & 0.831 \\
\hline Yes & $14(22.2)$ & $5(23.8)$ & $9(21.4)$ & & & \\
\hline No & $49(77.8)$ & $16(76.2)$ & $33(78.6)$ & & & \\
\hline Vaginal discharge & & & & 1.47 & $0.51-4.25$ & 0.472 \\
\hline Yes & $37(58.7)$ & $11(52.3)$ & $26(61.9)$ & & & \\
\hline No & $26(41.3)$ & $10(47.7)$ & $16(38.1)$ & & & \\
\hline VDRL test during prenatal care & & & & 2.28 & $0.67-7.75$ & 0.182 \\
\hline Yes & $47(78.3)$ & $14(66.7)$ & $33(84.6)$ & & & \\
\hline No & $13(21.7)$ & 7 (33.3) & $6(15.4)$ & & & \\
\hline VDRL titer & & & & 0.58 & $0.19-1.79$ & 0.352 \\
\hline$\leq 1: 4$ & $27(57.4)$ & $10(52.6)$ & $17(60.7)$ & & & \\
\hline$\geq 1: 8$ & $20(42.6)$ & $9(47.4)$ & $11(39.3)$ & & & \\
\hline Rapid test during prenatal care & & & & 0.50 & $0.15-1.64$ & 0.254 \\
\hline Yes & $40(66.7)$ & $16(76.2)$ & $24(61.5)$ & & & \\
\hline No & $20(33.3)$ & $5(23.8)$ & $15(38.5)$ & & & \\
\hline
\end{tabular}


Table 2 - Obstetric, prenatal and maternity health care for syphilis in pregnant women at the University Hospital of Dourados, Mato Grosso do Sul State (cont.).

\begin{tabular}{|c|c|c|c|c|c|c|}
\hline Variable & $\begin{array}{c}\text { Total } \\
\mathrm{n}=63\end{array}$ & $\begin{array}{c}\text { Case } \\
\mathrm{n}=21\end{array}$ & $\begin{array}{l}\text { Control } \\
n=42\end{array}$ & OR & $95 \% \mathrm{Cl}$ & $p$ value \\
\hline HIV serological test during prenatal care & & & & 0.34 & $0.03-3.12$ & 0.325 \\
\hline Yes & $54(90)$ & $20(95.2)$ & $34(87.2)$ & & & \\
\hline No & $6(10)$ & $1(4.8)$ & $5(12.8)$ & & & \\
\hline HIV serology & & & & 1.18 & $0.10-13.99$ & 0.892 \\
\hline Reactive & $3(5.6)$ & $1(5)$ & $2(5.9)$ & & & \\
\hline Non-reactive & $51(94.4)$ & $19(95)$ & $32(94.1)$ & & & \\
\hline Treponemal test during prenatal care & & & & 5.05 & $0.97-26.17$ & 0.053 \\
\hline Yes & $15(31.9)$ & $2(12.5)$ & $13(41.9)$ & & & \\
\hline No & $32(68.1)$ & $14(87.5)$ & $18(58.1)$ & & & \\
\hline Number of children & & & & 1.62 & $0.55-4.73$ & 0.375 \\
\hline$\leq 2$ & $29(46)$ & $8(38.1)$ & $21(50)$ & & & \\
\hline$\geq 3$ & $34(54)$ & $13(61.9)$ & $21(50)$ & & & \\
\hline Type of delivery & & & & 2.64 & $0.89-7.76$ & 0.077 \\
\hline VB & $34(54)$ & $8(38.1)$ & $26(61.9)$ & & & \\
\hline CS & $29(46)$ & $13(61.9)$ & $16(38.1)$ & & & \\
\hline Diagnosis of syphilis during pregnancy & & & & 0.88 & $0.26-2.97$ & 0.839 \\
\hline Yes & $47(74.6)$ & $16(76.1)$ & $31(73.8)$ & & & \\
\hline No & $16(25.4)$ & $5(23.9)$ & $11(26.2)$ & & & \\
\hline Treatment with penicillin & & & & 0.96 & $0.20-4.48$ & 0.960 \\
\hline Yes & $38(80.8)$ & $13(81.2)$ & $25(80.6)$ & & & \\
\hline No & $9(19.2)$ & $3(18.8)$ & $6(19.4)$ & & & \\
\hline VDRL test (monthly) & & & & & & 0.330 \\
\hline Yes & $4(8.6)$ & $0(0)$ & $4(13.4)$ & & & \\
\hline No & $43(91.4)$ & $17(100)$ & $26(86.6)$ & & & \\
\hline Sexual partner treated & & & & 0.76 & $0.19-2.97$ & 0.702 \\
\hline Yes & $22(46.8)$ & $7(50)$ & 15 (45.5) & & & \\
\hline No & 25 (53.2) & $7(50)$ & $18(54.5)$ & & & \\
\hline
\end{tabular}

$\mathrm{CS}$ = cesarean section; $\mathrm{VB}$ = vaginal birth; STI = sexually transmitted infections.

No newborns showed alterations in the X-rays of long bones. The CSF analyses showed that $42.8 \%$ $(9 / 21)$ of neurosyphilis cases had high protein $(>150 \mathrm{mg} / \mathrm{dL}), 28.6 \%(6 / 21)$ had a high number of leukocytes (>25 leukocytes $/ \mathrm{mm}^{3} \mathrm{CSF}$ ) and $28.6 \%(6 / 21)$ showed a positive VDRL test (Table 3). The clinical complications in newborns were $12.7 \%$ (8/63) of low birth weight and $34.9 \%$ $(22 / 63)$ of prematurity. In addition, $95.2 \%(20 / 21)$ of the cases and $28.5 \%$ (12/42) of the controls were hospitalized. The newborns with neurosyphilis were hospitalized for treatment for a minimum of ten days. Each case of neurosyphilis spent at least US\$ 64.21 with treatment (Brazilian reals were converted to U.S. dollars using the quotation of 09/28/2018, being R $\$ 4.03=1.00$ US\$), and $\mathrm{R} \$ 81.72$ per day with hospitalization. Thus, the health system spent around US\$ 881,48 on each patient with neurosyphilis.

\section{DISCUSSION}

In this study, we evaluated cases of neurosyphilis in Brazilian newborns. The results showed that most pregnant women received prenatal care and were diagnosed with syphilis during this period (treponemal test during prenatal care, $\mathrm{p}=0.053$ ). Although $80.8 \%$ pregnant women were treated with penicillin, only $46.8 \%$ of their partners received the treatment. Thus, inadequate treatment, mainly of sexual partners, may favor the vertical transmission of T. pallidum in pregnant Brazilian women. The alarming rise in syphilis cases in Brazil has become a serious public health problem, mainly due to severe complications resulting from the transmission of the infection to the fetus. However, improving the quality of health services to prevent the vertical transmission of T. pallidum in Brazilian pregnant women is still a challenge ${ }^{16}$. Our study identified a higher 
Table 3 - Complications in the newborns evaluated in this study.

\begin{tabular}{|c|c|c|c|c|c|c|}
\hline Variables & $\begin{array}{c}\text { Total } \\
\mathrm{n}=63\end{array}$ & $\begin{array}{c}\text { Case } \\
\mathrm{n}=21\end{array}$ & $\begin{array}{c}\text { Control } \\
\mathrm{n}=42\end{array}$ & OR & $95 \% \mathrm{Cl}$ & $p$ value \\
\hline VDRL titer & & & & 0.58 & $0.20-1.71$ & 0.330 \\
\hline$\leq 1: 4$ & $33(52.4)$ & $13(61.9)$ & $20(47.6)$ & & & \\
\hline$\geq 1: 8$ & $30(47.6)$ & $8(38.1)$ & $22(52.4)$ & & & \\
\hline Hospitalization & & & & 49.99 & $6.02-415.29$ & 0.003 \\
\hline Yes & $32(50.8)$ & $20(95.2)$ & $12(28.6)$ & & & \\
\hline No & $31(49.2)$ & $1(4.8)$ & $30(71.4)$ & & & \\
\hline Symptomatic syphilis & & & & 1.36 & $0.21-8.89$ & 0.743 \\
\hline Yes & $5(7.9)$ & $2(9.5)$ & $3(7.1)$ & & & \\
\hline No & $58(92.1)$ & $19(90.5)$ & $39(92.9)$ & & & \\
\hline Low birth weight & & & & 4.06 & $0.86-19.04$ & 0.075 \\
\hline Yes & $8(12.7)$ & $5(23.8)$ & $3(7.1)$ & & & \\
\hline No & $55(87.3)$ & $16(76.2)$ & $39(92.9)$ & & & \\
\hline Prematurity & & & & 2.27 & $0.76-6.73$ & 0.138 \\
\hline Yes & $22(34.9)$ & $10(47.6)$ & $12(28.6)$ & & & \\
\hline No & $41(65.1)$ & $11(52.4)$ & $30(71.4)$ & & & \\
\hline \multicolumn{7}{|l|}{ CSF abnormality } \\
\hline Protein (> $150 \mathrm{mg} / \mathrm{dL})$ & $9(42.8)$ & $9(42.8)$ & 0 & & & \\
\hline Leukocytes (> 25 white blood cells $/ \mathrm{mm}^{3}$ ) & $6(28.6)$ & $6(28.6)$ & 0 & & & \\
\hline Reagent VDRL & $6(28.6)$ & $6(28.6)$ & 0 & & & \\
\hline
\end{tabular}

incidence rate of congenital syphilis than reported in other studies $^{17-21}$. In addition, we showed that socio-economic variables, such as low income and poor education were frequent in this population, in agreement with those reported in the USA, China and Argentina ${ }^{22-24}$, possibly reflecting inequalities in self-care, as well as difficulties to access and perform follow-ups in health services.

Although health services adopt disease control measures for vulnerable groups such as the one of pregnant women ${ }^{14,15}$, they are insufficient to eliminate neurosyphilis. An untreated sexual partner is also associated with neurosyphilis, so that the exclusive treatment of pregnant women seems to be insufficient in reducing the incidence of congenital syphilis and neurosyphilis, thus reflecting a flaw in the follow-up. The treatment of sexual partners is vital for the interruption of the transmission chain and to avoid reinfection of pregnant women, considering that the use of condoms is uncommon ${ }^{25,26}$. Therefore, among the efforts to reduce the neurosyphilis cases, the treatment of the sexual partners cannot be neglected during the process of follow-up of pregnant women. Besides, condom use during prenatal care needs to be reinforced by health services as a way to identify strategies of negotiation with sexual partners to avoid permanent reinfection.
From the total of 21 reported cases of neurosyphilis, only 13 pregnant women and seven sexual partners were treated with penicillin. The exposure time of the fetus to T. pallidum may be responsible for the adverse outcomes in the newborns, as prenatal health and maternal vulnerability significantly impact the transplacental transmission of T. pallidum to the fetus. The delay in initiating treatment increases the exposure time of the fetus to T. pallidum and this is one of the critical factors determining the severity of the complications in syphilis ${ }^{27}$. Although the disease has a simple diagnosis and treatment ${ }^{14}$, our results indicate that the control of the transmission of this agent remains an unresolved challenge.

Most cases of neurosyphilis were hospitalized for treatment during a minimum of ten days, increasing the risks of exposure of the newborns to nosocomial infections. In addition, hospitalization represents high costs of at least US $\$ 881,48$ per case to the health system. However, these expenses could be reduced with proper prenatal care including the diagnosis and appropriate treatment of pregnant women and their sexual partners. In this study, 19 of 21 cases of neurosyphilis were asymptomatic. The most frequent alteration in the CSF was high protein levels. Moreover, the majority of cases 
of neurosyphilis in newborns were asymptomatic; the symptoms generally appeared later and were related to impaired neuropsychomotor development, which may lead to irreversible sequelae ${ }^{28}$. Due to the severe complications of neurosyphilis, maternal screening, and appropriate treatment during prenatal care are extremely important to reduce the number of T. pallidum infections in the fetus. Despite these results, there were some limitations in this study. Firstly, the total number of pregnant women with syphilis treated at the University Hospital in 2017 was 199 cases. However, only 63 pregnant women who gave birth to newborns infected with T. pallidum accepted to participate in the study.

The results of this study indicate that the control of the neurosyphilis remains an unresolved challenge. Late diagnosis of maternal syphilis and inadequate treatment and follow-up of sexual partners showed failures to provide proper prenatal care. Moreover, the high number of newborns hospitalized due to syphilis complications, increased, generating more spending to the Brazilian unified health system. For a more effective control of syphilis in pregnant women, treatment should be prioritized by health managers and professionals. Although the treatment of syphilis is inexpensive, some challenges need to be overcome to implement the guidelines of the Ministry of Health and the WHO guidelines to provide adequate treatment to pregnant women and their sexual partners. In addition, more studies are needed to identify possible obstacles faced by public health service professionals toward the effective management and control of syphilis in pregnant women.

\section{ACKNOWLEDGMENTS}

We are grateful to the University Hospital of Dourados for their support and to the participants, without whom this study could not have been performed. Our appreciation is also extended to the staff of the GPBMM/UFGD study group for their support.

\section{FINANCIAL SUPPORT}

This work was partially supported by the Conselho Nacional de Desenvolvimento Científico e Tecnológico (CNPq grant No 440245/2018-4), Fundação de Apoio ao Desenvolvimento do Ensino, Ciência e Tecnologia do Estado de Mato Grosso do Sul (FUNDECT grants N 092/2015 and 041/2017), Coordenação de Aperfeiçoamento de Pessoal de Nivel Superior (CAPES, grant 001) and Universidade Federal da Grande Dourados (UFGD).

\section{REFERENCES}

1. Avelleira JC, Bottino G. Sífilis: diagnóstico, tratamento e controle. An Bras Dermatol. 2006;81:111-26.

2. Santos MM, Lopes AK, Roncalli AG, Lima KC. Trends of syphilis in Brazil: a growth portrait of the treponemic epidemic. PLoS One 2000;15:e0231029.

3. World Health Organization. Department of Reproductive Health and Research. Investment case for eliminating mother-to-child transmission of syphilis: promoting better maternal and child health and stronger health systems. Geneva: WHO; 2012. [cited 2020 Sep 3]. Available from: https://www.who.int/ reproductivehealth/publications/rtis/9789241504348/en/

4. World Health Organization. Department of Reproductive Health and Research. Global incidence and prevalence of selected curable sexually transmitted infections - 2008. Geneva: WHO; 2012. [cited 2020 Sep 3]. Available from: https://www.who. int/reproductivehealth/publications/rtis/stisestimates/en/

5. World Health Organization. Global guidance on criteria and processes for validation: elimination of mother-to-child transmission of HIV and syphilis. $2^{\text {nd }}$ ed. Geneva: WHO; 2017. [cited 2020 Sep 3]. Available from: http://www.who. int/reproductivehealth/publications/emtct-hiv-syphilis/en/

6. Gomez GB, Kamb ML, Newman LM, Mark J, Broutet N, Hawkes SJ. Untreated maternal syphilis and adverse outcomes of pregnancy: a systematic review and meta-analysis. Bull World Health Organ. 2013;91:217-26.

7. Brasil. Ministério da Saúde. Secretaria de Vigilância em Saúde. Departamento de Vigilância Epidemiológica. Doenças infecciosas e parasitárias: guia de bolso. $8^{\mathrm{a}}$ ed. rev. Brasília: Ministério da Saúde; 2010. [cited 2020 Sep 3]. Available from: http://vigilancia.saude.mg.gov.br/index.php/download/ doencas-infecciosas-e-parasitarias-guia-de-bolso/

8. Brasil. Ministério da Saúde. Secretaria de Vigilância em Saúde. Sífilis 2018. Bol Epidemiol. 2018;49:1-43. [cited 2020 Sep 3]. Available from: http://www.aids.gov.br/pt-br/pub/2018/ boletim-epidemiologico-de-sifilis-2018

9. Menezes ML, Marques CA, Leal TM, Melo MC, Lima PR. Neurossífilis congênita: ainda um grave problema de saúde pública. J Bras Doenças Sex Transm. 2007;19:134-8.

10. Woods CR. Syphilis in children: congenital and acquired. Semin Pediatr Infect Dis. 2005;16:245-57.

11. Kingston M, French P, Higgins S, McQuillan O, Sukthankar A, Stott C, et al. UK national guidelines on the management of syphilis 2015. Int J STD AIDS. 2016;27:421-46.

12. Ghanem KG, Workowski KA. Management of adult syphilis. Clin Infect Dis. 2011;53 Suppl 3:S110-28.

13. Sparling PF. Diagnosis of neurosyphilis: new tools. Sex Transm Dis. 2010;37:288-9.

14. Macêdo VC, Lira PI, Frias PG, Romaguera LM, Caires SF, Ximenes RA. Risk factors for syphilis in women: case-control 
study. Rev Saude Publica. 2017;51:78.

15. Lago EG, Rodrigues LC, Fiori RM, Stein AT. Congenital syphilis: identification of two distinct profiles of maternal characteristics associated with risk. Sex Transm Dis. 2004;31:33-7.

16. Viellas EF, Domingues RM, Dias MA, Gama SG, Theme Filha MM, Costa JV, et al. Prenatal care in Brazil. Cad Saude Publica. 2014;30 Suppl 1:S85-100.

17. Bezerra ML, Fernandes FE, Nunes JP, Baltar SL, Randau KP. Congenital syphilis as a measure of maternal and child healthcare, Brazil. Emerg Infect Dis. 2019;25:1469-76.

18. Brasil. Ministério da Saúde. Secretaria de Vigilância em Saúde. Sífilis 2019. Bol Epidemiol. 2019;N Esp. [cited 2020 Sep 3]. Available from: http://www.aids.gov.br/pt-br/pub/2019/ boletim-epidemiologico-sifilis-2019

19. Wang Y, Wu M, Gong X, Zhao L, Zhao J, Zhu C, et al. Risk factors for congenital syphilis transmitted from mother to infant - Suzhou, China, 2011-2014. MMWR Morb Mortal Wkly Rep. 2019;68:247-50.

20. Slutsker JS, Hennessy RR, Schillinger JA. Factors contributing to congenital syphilis cases - New York City, 2010-2016. MMWR Morb Mortal Wkly Rep. 2018;67:1088-93.

21. Hong FC, Wu XB, Yang F, Lan LN, Guan Y, Zhang CL, et al. Risk of congenital syphilis (CS) following treatment of maternal syphilis: results of a CS control program in China. Clin Infect Dis. 2017;65:588-94.
22. Parker LA, Deschutter EJ, Bornay-Llinares FJ, Hernandez-Aguado I, Silva G, Piragine RD, et al. Clinical and socioeconomic determinants of congenital syphilis in Posadas, Argentina. Int J Infect Dis. 2012;16:256-61.

23. Umapathi KK, Thavamani A, Chotikanatis K. Incidence trends, risk factors, mortality and healthcare utilization in congenital syphilis-related hospitalizations in the United States: a nationwide population analysis. Pediatr Infect Dis J. 2019;38:1126-30.

24. Qin JB, Feng TJ, Yang TB, Hong FC, Lan LN, Zhang CL, et al. Risk factors for congenital syphilis and adverse pregnancy outcomes in offspring of women with syphilis in Shenzhen, China: a prospective nested case-control study. Sex Transm Dis. 2014;41:13-23.

25. Dallé J, Baumgarten VZ, Ramos MC, Jimenez MF, Acosta L, Bumaguin DB, et al. Maternal syphilis and accomplishing sexual partner treatment: still a huge gap. Int J STD AIDS. 2017;28:876-80.

26. Carreno I, Costa JS. Use of condoms during sexual intercourse: a population-based study. Rev Saude Publica. 2006;40:720-6.

27. Berman SM. Maternal syphilis: pathophysiology and treatment. Bull World Health Organ. 2004;82:433-8.

28. Centers for Disease Control and Prevention. 2015 sexually transmitted diseases treatment guidelines. [cited 2020 Sep 3]. Available from: https://www.cdc.gov/std/tg2015/default.htm 